Historic, Archive Document

Do not assume content reflects current scientific knowledge, policies, or practices. 



\section{Price List}

\section{of Stock From}

\section{The Atlantic Nursery}

and Small Fruit Farm

On Cemetery Road just South of Fair Grounds Atlantic - - Iowa

Owing to the advance of labor and almost everything one has to buy these days it keeps one busy to make ends meet, and to try and keep my prices down I have not put out a catalog, and this card is the only salesman I have and prices quoted on it are f. o. b. Atlantic, delivered to the freight or express office here. If you wish plants to go by parcel post add enough for postage to your order. I have built a nice Green House and will be glad to furnish you your vegetable plants.

Inspection Certificate with each shipment.

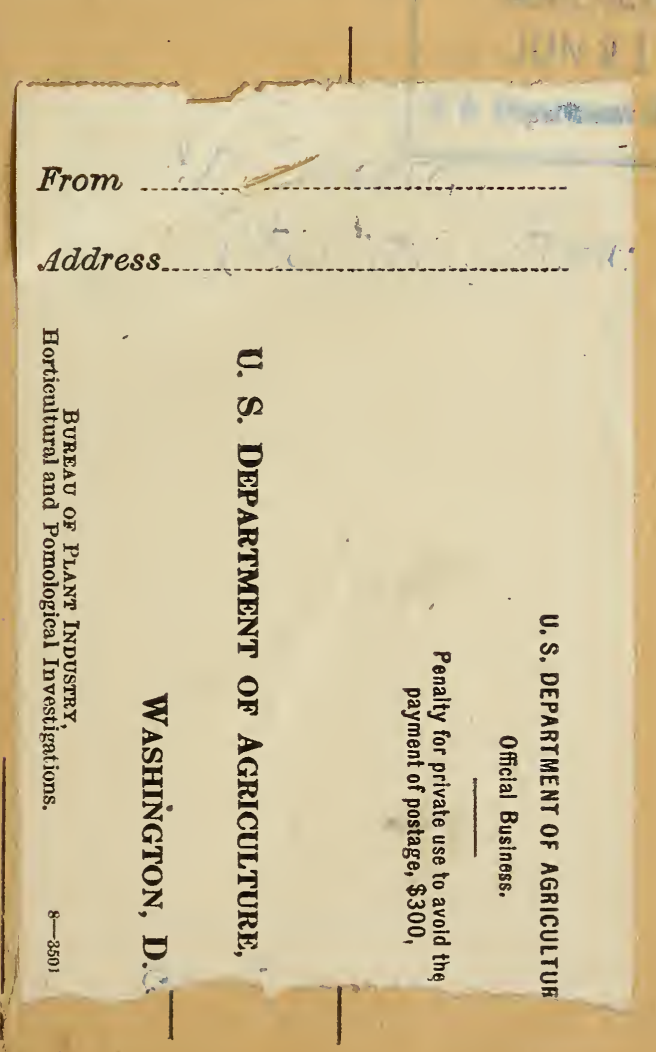




\section{APPLE TREES}

3 years old, 5 to 6 feet high, No. 1, price, each. $40 \mathrm{c}$

SUMMER VARIETIES

"Red June, Sweet June,"Duchess and Yellow Transparent.

FALL, VARIETIES

L. Wealthy and Famous or Snow.

WINTER VARIETIES

Gano, Wine Sap', Stayman, 'Jonathan, Grimes Golden, Ben Davis, Black Ben Davis, Minkler, Gennett, Arkansas Black, M. B. Twig, N. W. Greening, Delicious, King David, Price's Sweet, McIntosh.

CHERRIES-75c each

Varieties-Early Richmond, English Morello, Wragg and Montmorency.

\section{PLUMS-75c each}

Varieties - DeSota, 'Wyant, Hawkeye, Wild Goose, Terry, Moore/Arctic, Forest Garden.

PEACH-50c each

Varieties-Bokara, Elberta, Champion.

PEARS-75c each

Varieties-Keiffer, Flemish Beauty and Bartlett.

GRAPES-BLACK VARIETIES

Concord, 2 years old, 'each $20 \mathrm{c}$

Concord, 1 year old, each. $15 \mathrm{c}$

Worden and Moores, early, 2 years old, each..............25c Worden and Moores, early, 1 year old, each ……….......15c Agawam Red, each......... White M. Diamond, and Niagara, each. $25 \mathrm{c}$ CURRANTS-RED VARIETIES

One year, each $15 \mathrm{c}$

Two Year, each... $25 \mathrm{c}$

Red Dutch, Cherry, North Star and London Market, White Grape, each $15 c$

GOOSEBERRIES, at the same prices as to age as Currants. Varieties-Downing, Houghton and Champion.

\section{BLACK RASPBERRIES}

$\$ 3.00$ per 100 , no orders booked for less than 25 of a kind. Varieties-Kansas, Gregg, Cumberland, Nimeha and Plum Farmer.

\section{RED VARIETIES}

Louden is the only one that has proved profitable with me. The same price as the black. 
ASPARAGUS, CONOVEYS AND PALMETTO

$25 \mathrm{c}$ per dozen; $\$ 1.00$ per 100 .

RHUBARB OKR PIE PLANT

$25 \mathrm{c}$ each or $\$ 1.00$ per lozen large roots.

\section{STRAWBE'RRY PLANTS}

Varieties-Dunlap (\$), Fendall (S), Lovett (S), Haverland (S), Aroma (S), Sample (P), Warfield (P)

Varieties marked $P$ are imperfect and should have varieties'marked S. plaf ed with them or they will not fruit satisfactorily. Pri $\$ 1.00$ per $100 ; \$ 5.00$ per 1000 , by express.

Progressive Everbea ing Strawberries, \$2.00 per 100.

\section{ORNAMENTAL AND SHADE TREES}

Cut Leaved Weeping Birch, each.

Sugar Maple 1.00

Mountain Ash $.75 \mathrm{c}$

American Elm $75 \mathrm{c}$ and 1.00

Carolina Poplar $35 \mathrm{c}$ to $75 \mathrm{c}$

Camper Down Weeping Elm. .1 .00

Weeping Mountain Ash. $75 \mathrm{c}$

Weeping Mulberry $75 \mathrm{c}$

Weirs' Cut Leaved Maple. $75 \mathrm{c}$

\section{FOREST TREE SEEDLINGS}

American or White Ash, Russian Mulberry, Box Elder and Catalpa Speciosa, at, per 100 .

\section{ROSES-Two-year Field Grown}

Crimson Rambler $50 \mathrm{c}$

Dorothy Perkins $50 \mathrm{c}$

Paul Neyron $50 \mathrm{c}$

Gen. Washington $.50 \mathrm{c}$

Mad Plantier $.50 \mathrm{c}$

Persian Yellow $50 \mathrm{c}$

Sol De Orr. $50 \mathrm{c}$

Gruse and Teplitz. $.50 \mathrm{c}$

Baby Rambler $.50 \mathrm{c}$

Conrad F. Meyer $.50 \mathrm{c}$

Madame Geo. Bruent. $.50 \mathrm{c}$

Rugosa Alba $.50 \mathrm{c}$

Rugosa Rubra $.50 \mathrm{c}$

Snow Ball $.50 \mathrm{c}$

Hydrangea, hardy bush form $50 \mathrm{c}$

Double Flowering Plum. $75 \mathrm{c}$

Tree Hydrangea $.75 \mathrm{c}$

Bechtals Double Flowering Crab. $.75 \mathrm{c}$

Lilac, Purple, White or Persian, each $50 \mathrm{c}$

Spirea or Bridal Wreath. $50 \mathrm{c}$ 
Wegelia Rosea

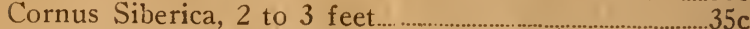

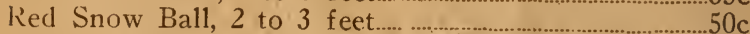

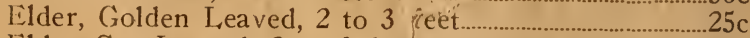

Elder Cut Leaved, 2 to 3 feet …………………………25

Honeysuckle in Red, White, and Pink, 2 to 3 feet, each

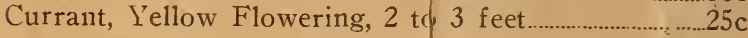

\section{VINES AND CRIEEPERS}

Clematis in white, purple and ink, each..................50c

Wisteria in white and purpl. ..................................

American and Vitchii Ivy ..............................................

\section{BULBS AND TLRERS}

Peoinies in red, white and pink, each

Dahlias in red, variegated and white.

Cladiolas, in best mixtures.

Lilies Tigrum

Bleeding Heart

Iris German, in about all shades

Golden Glow 10 c, 3 for $25 c$

$5 \mathrm{c}$ $25 \mathrm{c}$ $35 \mathrm{c}$ $15 \mathrm{c}$ $15 \mathrm{c}$

ORNAMENTAL HEDGING

California Privet, 18 to 24 inches, per 100

Ibota, 18 to 24 inches.

Barberry Thumbergii, 18 to 24 inches

\section{EVERGREENS}

In different prices, owing to size and kind. Twice transplanted, for windbreaks, 10 to 12 inches, per hundred $\$ 10.00$. In Norway, Spruce, White Pine, and Scotch Pine.

For larger sizes and selected kinds, write your wants, or better still, come and dig them yourselves and you will be sure to get the ones you want.

Prices of VEGETABLE PLANTS, postpaid Tomato, per dozen. $15 c$ Earliana, Beef Steak, Stone and Perfection Cabbage, per dozen $15 c$

Early Jersey Wakefield, All Seasons, Copenhagen and Flat Dutch

Cauliflower, per dozen

Celery

Mango Pepper

Cayenne Pepper Sweet Potatoes $15 \mathrm{c}$ $15 \mathrm{c}$ $15 \mathrm{c}$ $15 \mathrm{c}$ per dozen, $75 \mathrm{c}$ per 100 Write for prices on large lots by express

Geraniums, 15 and 20 cents.

Ferns from $25 \mathrm{c}$ to $\$ 1.00$.

Foliage plants, 5 and 10 cents.

Salvia, Lilies, Vinca, Ivy, for Porch Boxes and Baskets.

A good assortment of lianging Baskets.

Green house stock of all kinds. 